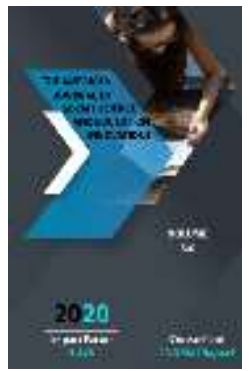

Journal Website: http://usajournalshub.c om/index,php/tajssei

Copyright: Original content from this work may be used under the terms of the creative commons attributes 4.0 licence.

\section{Methodology For Raising And Motivating Cadets Of Military Educational Institutions For Education And Research Activities On The Example Of The Topic: The Role Of The Italian Revival In The Spiritual And Cultural Revival Of The European Nation}

\author{
Guzal Alisherovna Alimova \\ Doctor Of Philosophy (Phd) In Economics, Lecturer, Military-Technical Institute Of The \\ National Guard Of The Republic Of Uzbekistan
}

\title{
ABSTRACT
}

This article discusses the role of the Italian revival in the spiritual and cultural revival of the European nation: on the methodology of educating and motivating cadets of military educational institutions for educational and research activities in the example of the topic. In the course of the research, the methods of analysis and synthesis, historical-statistical, civilizational approach, comparative-historical analysis, gender and socio-cultural approach, etc. were used. Historical and retrospective analyzes have revealed a direct link between the European Renaissance and the formation of a new worldview, the transition to another stage of civilization, which is reflected in other areas of economics, politics and human activity provided with innovations and innovative solutions. The article also focuses on the development of the family and the role of women in society. In order to determine the practical significance of the theoretical research, an experiment was conducted to determine the impact on the cadets of the problem under consideration, followed by monitoring their development and at the same time their interest in learning.

\section{KEYWORDS}

Civilization, renaissance, culture, worldview, industrial revolution, reformation, economy.

\section{INTRODUCTION}

In the last three hundred years, it would have been impossible for the world to develop its materially modern civilization without spiritual development, without the widespread dissemination of its most important values, such as culture, scientific ideas, and technical 
achievements. Modern society is faced with a problem that we conventionally designated as a "cultural crisis". At the same time, the destructiveness of the "cultural crisis" is characterized by its scale, since culture covers all aspects of the life of society: production, economic, political, artistic, managerial, etc. According to the established tradition in science, the term "Great Renaissance" or "Renaissance" (from the French Renaissance) refers to the revival of the classical antiquity [2].

The experience of the development of civilizations shows that the phenomenon called "renaissance" is a process that occurs at a certain moment and has its own cyclical nature. So in his work "The Decline of Europe" O. Spengler (1880-1936) notes that the development cycle of each individual culture is approximately 1500 years. A deep antiquity period began before the Civilization phase (among Europeans it began in 500, marked by the fall of Rome and the beginning of the Merovingian period). This is followed by a real phase of culture that lasts for 1000 years. And finally, a stage of civilization begins, lasting 200-300 years. Spengler describes the alternation of three stages of development as a change of seasons: spring, summer, autumn, winter.

In our opinion, each civilization has its own energy, the depletion of which leads to a change in culture itself up to the prevalence of primary physiological needs over non-material culture.

In Europe, this was a special period of cultural and spiritual development. Its significance lies in the fact that, first of all, the movement of thought caused the transition of the peoples of these countries from medieval culture to the culture of the New Age. That is, there was a revival of the energy of the people, the awakening and awareness of the former belonging to the high culture of "Rome", "Ancient Greece".

The era of the Great Renaissance marked the end of the "dark ages" in the history of Europe, which lasted for about 750 years (between the 5th and 12th centuries) and were characterized by the decline of classical Greco-Roman culture, degradation of the intellectual and social life of society in the previously civilized parts of the ancient world [15].

\section{MAIN PART}

The Italian Renaissance was of exceptional importance in the formation of the modern world order, the development of science, culture, social and human outlook. The scale of the Renaissance is striking in its depth, and the territories go far beyond the borders of Italy, covering the entire European civilization. Poetry, music and art in various forms occupied a special place in the life of all strata of society. That is why art became a breath of clean air, a need for people in the Renaissance era, an expression of their inexhaustible creative energy [18]. The results of the development of art are the erected monuments, magnificent architectural buildings and structures. Brilliant scientists, philosophers, artists worked and lived here They are Leonardo Da Vinci, Michelangelo Buanarotti, Titian and others [17].

Speaking about trade with the East, it should be noted that it led to the flourishing of the city-republics of Northern Italy, to the formation of commercial, merchant capitalism. Here one of the epoch-making inventions on the way to a new social order was introduced - double Italian bookkeeping, 
which made it possible to organize careful accounting of big money and many clients [5]. The accumulation of capital, the expansion of the market framework far beyond the borders of not only the state, but also to the regions, gave rise to a new capitalist mode of production - Manufacturing. This is the first type of large enterprise, based on the subdivision of manual and partially mechanized labor, sharply increased labor productivity, the range and quality of manufactured goods and, in turn, demanded new sales markets.

\section{Economic Prerequisites for the Development of the Renaissance in Italy}

The period "before the Renaissance" was characterized by a deep economic crisis in Italy: it was both increased competition from the northern countries, and the fact that merchants and bankers began to withdraw capital invested in industry and trade, investing them in real estate - land ownership. At the end of the 15th century, five powerful city-states were formed in Italy (although there were other independent regions of Italy): [25].

- Papal States;

- Florence;

- Venice;

- Milan;

- Genoa.

The cultural transition created the preconditions for the transition of Europe from feudalism to capitalism. As the predominant form of economy, capitalism began to function from the end of the 15th century on a narrow strip of land - from Italy, through Upper Germany and the Rhineland to the Netherlands. It should be noted that of all this territory only in Italy are developed regions - Venice, Genoa. These city-states, formed at the junction of sea and land routes, had comparative advantages. They occupied a dominant position in the eastern Mediterranean in trade with the Arab countries and became politically and economically independent. Florence became an equally important city-state, which was the center of industry and usury [19].

Trade is a feature of these three areas. They were a trade link with the East. Silks, precious stones and products, spices and other goods came to Europe precisely through these regions of Italy.

Florence played a special role in the history of the Great Renaissance. This region was one of the richest in Europe, a manufactory was born here, a wool processing and silk-weaving industry was developed.

Another industrial center was Milan. The production of silk cloth and weapons flourished here. [12].

Note that although the trading centers in the western part of the Mediterranean were Marseille (Southern France), Barcelona on the Iberian Peninsula, their importance in trade with the East was not yet great. Major trade relations with the East were established only by the cities of Northern Italy. [23].

As a result of active economic activity, capital accumulation, expansion of markets took place, and a new mode of production manufacturing - was formed.

Separately, I would like to note that the cultural revival that broke out in Italy was the impetus for economic development.

While researching the role of the Italian Renaissance, we wondered where in Italy the first spark of the Renaissance originated? 
Florence - this particular region of Italy is "the cradle of the Great Renaissance of Europe". But why exactly Florence became "the cradle of the Great Renaissance of Europe"?

At the time, Florence was the center of usurious capital. Credits played an important role in the economic life of Europe. In the absence of a unified system in medieval Europe, as well as in the slave-owning world, special money changers became necessary to improve and carry out trade operations, who would also be engaged in the transfer of money. If the merchant took with him the necessary money supply in silver, then this would take up as much space as all his goods. In addition, in the face of road hazards, this was not possible. Therefore, the merchant gave a certain amount to the money changers, who instructed their agents to issue it upon presentation of a bill of exchange. The settlement system was also an achievement of Florentine merchants, who avoided money laundering and simplified trading operations. The money changers received the name of bankers - "bank" in Italian "bench", that is, the usual place of "work" of the money changer.

With the development of trade and industry, banking and credit acquired great economic importance.

The largest trading house in the middle Ages was the Florentine Medici firm. She had branches in many cities in Europe. These offices carried out promissory notes, loans, commissions, insurance operations and both for small and large clients, sometimes loans were issued to powerful kings of Europe and could be decisive in winning the victory in wars. The Medici credited the entire wool industry of Florence.

\section{Gender And The Development Of Science As A Result Of The Renaissance}

Florence became the cradle of the Great Renaissance. In our opinion, the contribution of a great person like Lorenzo Medici, who earned the nickname "magnificent", is invaluable. This man was ahead of his time and loved all the beautiful things, and despite the serious threats of the Inquisition, he surrounded himself with philosophers, poets, musicians, and other peculiarities. The Medici circle developed philosophical problems in the spirit of Neoplatonism, the legacy of ancient Greek authors being studied with particular care and translated into Italian.

In Italy at the time, the woman did not act as a full member of society, and her role was largely limited to reproductive and family responsibilities. Especially in the Papal States, very young and ignorant girls were valued, believing that an intelligent and competent wife is a punishment for the family. But the Florentine woman was distinguished by education, culture of conducting scientific conversation, etc. Florentines began to feel that it was necessary to pay special attention to the role of women in the development of society [9]. Girls were the first grocery stores in the East to have access to rare manuscripts and books of ancient Greek philosophers, mathematical calculations, physics, and the origins of the world, and even a religious approach. It was impossible to get out. Of course, Rome considered such an attitude of women to science to be heresy [20]. However, the most attractive Florentine bride is this educated and having her own position regarding events and phenomena, which is able to defend and justify her, that is, an accomplished personality with a sharp mind. 
The Attitude towards the Institution of the Family has Changed Radically

Now the family is the stability and purity of the relationship between woman and man, although celibacy is almost non-existent by Catholics, who saw it as the highest level of existence. Being a spinster or bachelor in Italian business is increasingly becoming a sign of any shortcomings, and even such people have been the object of ridicule [1].

However, we cannot generalize the situation of women of the Renaissance with those positive phenomena that were in Florence, and even they did not cover all strata of society.

At the same time, this period influenced the strengthening of the institution of the family, which spread throughout Italy and allowed women to receive certain social and financial guarantees, but the fate of a woman remained difficult: [6].

- These are early marriages, as a result, high maternal and child mortality (per woman during the fertile period, about 6-10 pregnancies);

- Constant wars and, as a consequence, the death of the male population, which, in turn, created social tension in the family. Widows often did not have a certain specialty and the opportunity to earn money; they either left for a monastery, where they also tried to accept women who could pay the initial payment, or begged.

I would like to note that the conclusion of marriages, which were more like not a union of two lovers, but like a contract that is designed to solve financial, political or other problems. [7].
The Influence of the Renaissance on the Change in Spiritual Values

Speaking of spiritual values, we note that the golden age of the Italian Renaissance was in step with the fury of the Inquisition, Its cruel measures and the strongest position of the Catholic Church in the world political arena. It is surprising that the spark of the Renaissance "flashed at the side of Rome."

One of the first to question the fairness of some of the decisions made by Pope Sixtus IV was Lorenzo Medici. [13]. Lorenzo Medici also established himself as a far-sighted and subtle politician, strategist, who skillfully kept the political balance in Italy. However, Lorenzo at times took harsh and unprecedented measures against the Papal policy [14]. So, after an unsuccessful attempt on Lorenzo's life, organized with the support of the Pope, his brother Giuliano died. Lorenzo was hanged in a humiliating form (upside down) of the papal vassal in the Piazza della Signoria, after which he was excommunicated. However, long-term conspiracies and Natski affected the commercial city-republics of Italy [3]. As a result, Italy, being the center of the common European religion - Catholicism, managed to breathe life, laying the foundation not only for humanistic, democratic values, but also for the revival of Europe.

However, the spirit of modern times could not be stopped. The ideas of the Italian Renaissance became one of the stimuli for the reformation of the church.

The movement towards the reformation, which began in Germany, led, in particular, to the establishment of the independence of religion on a national basis, to the formation of the Lutheran church itself. [22]. 
The wind of change was picked up by England - the Church of England. Protestantism played a decisive role in the formation of the modern world order, since the main postulates of Protestantism almost exactly correspond - to capitalism [10]. So, wealth is considered by Protestants as a duty to God, he created a person to find and realize all the opportunities (entrepreneurship) to become rich, and poverty and poverty are sin.

Now we ask ourselves the question: "Why did the industrial revolution that caused the European economic breakthrough take place in England?"

Officially, the creator of the steam engine is James Watt (1782), but as early as 1615 a device powered by steam was created by the French inventor Solomon de Cau, from 1763 to this study showed that the main engine of progress is culture and science. In order to apply the obtained theoretical results in practice, in the 2019-2020 academic year, an experiment was conducted in 3 training groups with cadets of the Military-Technical Institute of the National Guard of the Republic of Uzbekistan, which we conditionally identified as group 1, group 2, group 3, subjects: "World Economy", "Economic Geography and Ecology" [8].

Experiment procedure:

1. The issue under study was described in detail and discussed at a lecture.

2. in seminars:

- In the first group (28 people, for 2 pairs of classes) - an "class conference" was held on the topic: "Problematic aspects of spiritual and cultural development of youth in the formation of a modern and dynamically developing Uzbekistan." The main speakers (8 people) on the topic, participants (18 people) and conference organizers (2 people) were identified. During the conference, the cadets
1766. The operating steam engine was created in Russia by Ivan Polzunov. However, these inventions did not find practical application, and the James Watt steam engine, one might say, was long-awaited and became the basis for the development of light industry and made it possible to solve the transport issue (steamboats, steam locomotives, etc.). Entrepreneurs began to conquer new markets with frantic speed, firmly entrenched in the international division of labor in the main sectors of the economy [21].

Methods for raising and motivating cadets for education and research activities on the example of the topic: The role of the Italian revival in the spiritual and cultural revival of the European nation.

The development of civilizations occurs under the influence of accompanying factors, but

identified the main problems on the issue under discussion. Mechanisms and ways of solving these problems have been developed. The conference participants, using the method of "critical analysis" of the judgments offered by the speakers, actively discussed the problems. It should be noted that the cadets in the process of preparing and holding the classroom conference deeply and with interest studied the topic given to them. 


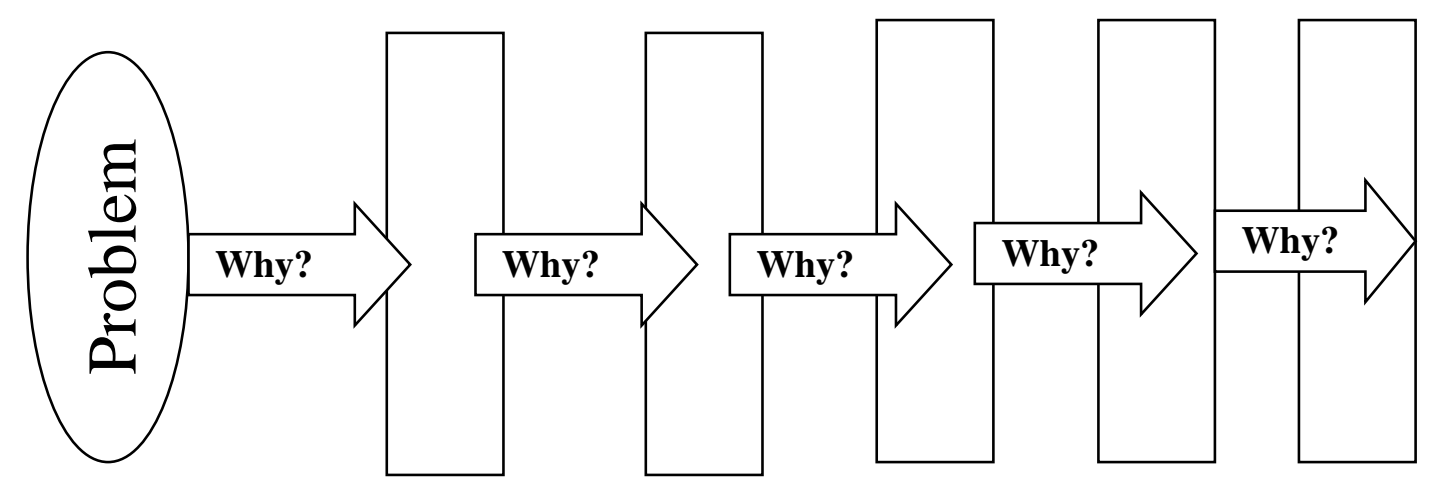

Figure 1 Diagram of the "Why?" Method

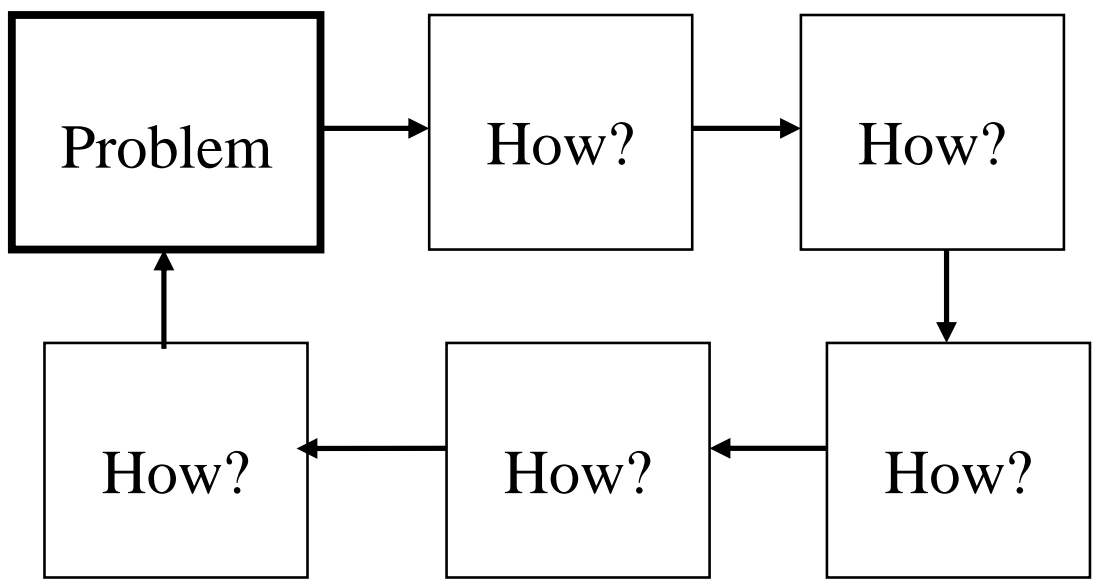

Figure 2 Scheme of the "How?" Method

- In the second group (26 people, for 1 pair of lessons) - methods "Why? "And How?" (Fig. 1, 2). A feature of these methods is the motivation in the systematization of knowledge, suggestions and judgments of the student. The cadets were divided into two subgroups of 13 people - the first subgroup was given a task according to the "Why?" Method, namely, "Why is there a need for highly qualified personnel in Uzbekistan today?"

Cadets in a certain schematized form should, on the basis of the "evolutionary approach":

1. identify the problem with an indication of the main reasons;

2. The development of the problem;

3. Current state of the problem.
The second subgroup was given a task (according to the "How?" Method) to develop mechanisms for solving the task: "How to increase the spiritual and cultural development of modern personnel?" Here, the cadets had not only to develop a mechanism for the implementation of the task, but also to systematize the activities determined by them in stages [4].

- In the third group (24 cadets) was given the task of writing an "Essay" on the topic: "Spiritual and cultural revival of the nation - the basis of the socio-economic development of the country" [15]. 
The group was divided into four subgroups ( 6 people each) for writing essays of the following types:

a) The first subgroup writes a "descriptive essay", where the set topic is considered in evolutionary order;

b) The second subgroup writes "an essay of a causal nature", here the cadets should try to understand the reasons for raising such a problem;

c) The third subgroup writes a "comparative essay", here the cadets work on the principle of a comparative analysis of the problem posed;

d) The last - the fourth subgroup writes an "analytical Essay", here the cadets present the results on the studied issue, describe their thoughts and conclusions, and can also present their proposals on the topic.

It should be noted that in all three study groups the topic under study aroused increased interest; in the process of work, the cadets' feeling of involvement in the processes taking place in society was strengthened.

Most of the cadets noted the fact that they needed to study the training material more deeply, the level of motivation of the cadets to study was tangible.

In this regard, we have monitored the progress of cadets of groups 1.2.3.

Table 1

Monitoring the progress of cadets in groups 1.2.3 at the end of the 1st semester of the 2019/2020 academic year

\begin{tabular}{|c|c|c|c|c|c|c|c|c|c|c|c|}
\hline \multirow[t]{2}{*}{ № } & \multirow[t]{2}{*}{$\begin{array}{l}\text { Study } \\
\text { group }\end{array}$} & \multirow{2}{*}{ 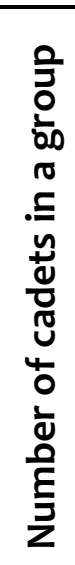 } & \multicolumn{2}{|c|}{$\begin{array}{c}\text { At the end of } \\
\text { the 1st } \\
\text { semester, } \\
\text { cadets with an } \\
\text { excellent rating }\end{array}$} & \multicolumn{2}{|c|}{$\begin{array}{l}\text { At the end of } \\
\text { the 1st } \\
\text { semester, } \\
\text { cadets with } \\
\text { good grades }\end{array}$} & \multicolumn{2}{|c|}{$\begin{array}{l}\text { According to the } \\
\text { results of the 1st } \\
\text { semester, cadets } \\
\text { have satisfactory } \\
\text { grades of cadets }\end{array}$} & \multirow[t]{2}{*}{ 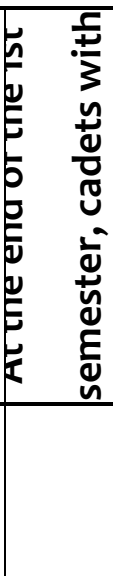 } & \multirow[t]{2}{*}{ 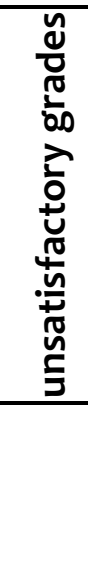 } & ఏ̊ำ \\
\hline & & & $\begin{array}{c}\text { Peopl } \\
\text { e }\end{array}$ & in $\%$ & $\begin{array}{c}\text { Peopl } \\
\text { e }\end{array}$ & in \% & $\begin{array}{c}\text { Peopl } \\
\text { e }\end{array}$ & in $\%$ & & & \\
\hline 1 & 1-group & 28 & 3 & $10,71 \%$ & 20 & $71,43 \%$ & 5 & $17,86 \%$ & & & \\
\hline 2 & 2-group & 26 & 4 & $15,38 \%$ & 16 & $61,54 \%$ & 6 & $23,08 \%$ & & - & \\
\hline 3 & 3-group & 24 & 3 & $12,50 \%$ & 15 & $62,50 \%$ & 6 & $25,00 \%$ & & - & \\
\hline & $\begin{array}{l}\text { Гotal / } \\
\text { verage } \\
\text { ade in\% }\end{array}$ & 78 & 10 & $12,82 \%$ & 51 & $65,38 \%$ & 17 & $21,79 \%$ & & - & \\
\hline
\end{tabular}




\section{Table 2}

\section{Monitoring the progress of cadets in groups 1.2.3 at the end of the 2nd semester of the 2019/2020 academic year}

\begin{tabular}{|c|c|c|c|c|c|c|c|c|c|}
\hline \multirow[t]{2}{*}{ № } & \multirow[t]{2}{*}{$\begin{array}{l}\text { Study } \\
\text { group }\end{array}$} & \multirow{2}{*}{ 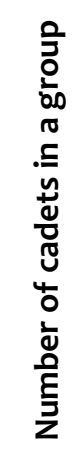 } & \multicolumn{2}{|c|}{$\begin{array}{l}\text { At the end of the } \\
\text { 2nd semester, } \\
\text { cadets with an } \\
\text { excellent rating }\end{array}$} & \multicolumn{2}{|c|}{$\begin{array}{l}\text { At the end of the } \\
\text { 2nd semester, } \\
\text { cadets with good } \\
\text { grades }\end{array}$} & \multicolumn{2}{|c|}{$\begin{array}{l}\text { According to the } \\
\text { results of the 2nd } \\
\text { semester, cadets } \\
\text { have satisfactory } \\
\text { grades of cadets }\end{array}$} & \multirow[t]{2}{*}{ 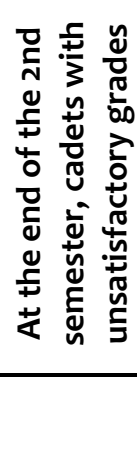 } \\
\hline & & & People & in $\%$ & People & in $\%$ & People & in $\%$ & \\
\hline 1 & 1-group & 28 & 6 & $21,43 \%$ & 19 & $67,86 \%$ & 3 & $10,71 \%$ & - \\
\hline 2 & 2-group & 26 & 4 & $15,38 \%$ & 18 & $69,23 \%$ & 2 & $7,69 \%$ & - \\
\hline 3 & 3-group & 24 & 5 & $20,83 \%$ & 16 & $66,67 \%$ & 3 & $12,50 \%$ & - \\
\hline & $\begin{array}{l}\text { / Average } \\
\text { ade in\% }\end{array}$ & 78 & 15 & $19,23 \%$ & 53 & $67,95 \%$ & 8 & $10,26 \%$ & - \\
\hline
\end{tabular}

The results of the monitoring showed that in study groups 1, 2, 3, where the experiment was conducted, there is a positive trend. So, according to the results of the first semester in group 1, 3 cadets or $10.71 \%$ graduated with excellent marks, and by the end of the second semester this number increased to $6-21.43 \%$, but the number of good students decreased from 20 cadets to 19 or from $71,43 \%$ to $67.86 \%$. It should be noted that the number of cadets with a "satisfactory" grade decreased from 5 cadets to 3 .

In group 2, there is also a positive dynamics in the performance of cadets, although the number of cadets who graduated from 1 and 2 semesters with an "excellent" grade remained unchanged, namely $15.38 \%$ or 4 cadets, but the number of good students increased from 16 to 18 or from $61,54 \%$ to $69.23 \%$ The number of cadets with satisfactory academic performance decreased from $23.08 \%$ to $7.69 \%$.
In the third group, the number of excellent cadets increased from 3 to 5 and amounted to $20.83 \%$, and good students increased from 15 to 16 and amounted to $66.67 \%$, the number of cadets with a "satisfactory" grade decreased from 6 to 3. It should be noted that the overall performance with a positive assessment in all three study groups increased from $78.20 \%$ to 87.18\%. The experiment showed that deep theoretical research can be effectively assimilated in the learning process and can be easily applied in practice.

\section{CONCLUSION}

Our analysis allows us to draw several key conclusions:

1. The Italian Renaissance Anglican Church became a necessary condition for the reform and formation of Protestantism. The basic tenets of Protestantism are identical with the norms of capitalism, which speaks of the awakening of the energy of the people of England, who began to feel the need for a new one, and 
this was the primary factor in the emergence of the industrial revolution.

2. The socio-economic development of the country and peoples is based on spiritual and cultural development! This statement is confirmed by the Italian Renaissance, when spiritual and cultural renewal became a powerful impetus for the economic development of the northern city-states of Italy. Financial mechanisms for managing the economy were developed, many of which have not lost their relevance.

3. During the Italian Renaissance, not only did attitudes toward the institution of the family change, and a strong and prosperous family became an indicator of well-being, but the status of women was also viewed from a different perspective.

4. The problem under discussion is interesting and useful in the learning process. The results of the study aroused interest among the cadets of the MilitaryTechnical Institute of the National Guard of Uzbekistan and made them think about the contribution of each person to the development of their homeland.

a) The study showed that the harmonious development of society, family and personality is inextricably linked with the level of spiritual and cultural development of the country.

\section{REFERENCES}

1. Abramson M.L. Alexandra Strozzi and her family (Florence, 15th century) // Man in the world of feelings. Essays on the history of private life in Europe and some Asian countries before modern times. Ed. Yu.L. Bessmertny. Moscow: 2000. -pp. 29-69. URL: https://elibrary.ru/item.asp?id=1513832

4.

2. Brockhaus F.A. Efron IA Encyclopedic Dictionary in 86 volumes. St. Petersburg: 1890-1907. URL: https://elibrary.ru/item.asp?id=1915435

7.
3. Burdah K. Reformation, Renaissance, Humanism. Moscow: "Russian political encyclopedia” (ROSSPEN), 2004. pp.101-109. (Series "Book of Light”) URL: https:

//www.elibrary.ru/ip/D5995782.

4. Gorbunova E.E. Classification of teaching methods in modern pedagogical science // Young scientist. 2015. No. 11 (91). S. 132-149. URL: https://moluch.ru/archive/91/19746.

5. Dmitrieva N.A. A Brief History of Art. Moscow: Publishing house of Art, 1975, -pp. 87-103. URL: https://elibrary.ru/item.asp?id=1980144 1.

6. Davis N.Z; Farge A. Women as protagonists of history // History of women. The paradoxes of the Renaissance and Enlightenment. Saint Petersburg: Aleteya, 2008, -pp. 151-156. URL: https://studwood.ru/537430.

7. Duby J; Perrault M. Telling the story of women // History of women in the West: In 5 volumes. Vol. 1: From ancient goddesses to Christian saints / Ed. P. Schmitt Pantel. Moscow; Aleteya, 2005. -p. 210-215. URL: https://www.liveinternet.ru/users/stea mpunk3d/post422084097.

8. Koshenkova N.V. About the essence of cognitive interest and its role in learning // Theory and practice of education in the modern world: materials of the VI International. scientific. conf. (St. Petersburg, December 2014). St. Petersburg: Zanevskaya square, 2014.-pp. 202-204. URL:

https://moluch.ru/conf/ped/archive/145 16718.

9. Krasnova I.A. Traditions and innovations in the study of the history of women in Tuscany XIV-XV centuries. // Methodological and historiographic questions of historical science. Issue 28.Tomsk, 2007. -pp. 196-211.URL: https://elibrary.ru/item.asp?id=294075. 
10. Max Weber. Protestant ethics and the spirit of capitalism. Moscow: East View,2002.-pp.55-58. URL: https://search.rsl.ru/ru/record/0100291 7249.

11. Markaryan E.S. Cultural theory and modern science. Moscow: Mysl', 1983. -pp. 26-33. URL: https://www.elibrary.ru/ip_restricted./ 17075748.

12. Muravyova L.A. Banks of medieval Europe // Finance and credit. No. 26. pp.57-68.

URL: https://elibrary.ru/item.asp?id=2377589 2.

13. Obraztsova A. G., Salnikova E.V. England. Theater. // Art history of Western Europe from the Renaissance to the beginning of the twentieth century. 19th century art. England. Scandinavia. Eastern Europe. Collective monograph. III book. St. Petersburg: Publishing house Dmitry Bulanin, 2004. - pp. 47-100. URL: https://elibrary.ru/item.asp?id=200878 89.

14. Pankina E.V. Carnival triumph in the life and work of Lorenzo Medici // House of Burganov. Space of culture. 2015. No. 1. - pp. 89-114. URL: https://www.elibrary.ru/item.asp?id=23 603178.

15. Guseva M.S; Dmitrieva E.O. Regional economics and management: methodology of an academic essay: study guide. Benefit. Samara: Publishing house Samar. state econom. University, 2017.-pp 15-19. URL: https://elibrary.ru/item.asp?id=325006 74.

16. Rotenberg E.I. The Art of Italy. Moscow: Izd-vo Art, 1974. -pp. 12-26. URL:

https://search.rsl.ru/ru/record/0100720 6088.

17. Sergeev K.A. The Renaissance Foundations of Anthropocentrism.
SPb: 2007. -pp. 388-390. URL: https: //www.elibrary.ru/ip_restricted.asp? Rpage.

18. Titarenko I.N. History of culture of the Ancient East. Taganrog: TTIUFU Publishing House, 2010.-pp. 140-152. URL: https://elibrary.ru/title_about.asp?id=5 0654.

19. Travin D. Ya. At the origins of modernization: Russia against a European background (second report). Publishing House of the European Universityat St.Petersburg; 2013.-pp.18-22. URL: http://new.pdfm.ru/35ekonomika/12127 1.

20. A History of Women's writing in Italy. Ed. by L. Panizza, S. Wood. Cambridge. 2000. -pp. 26-31. URL: Error! Invalid hyperlink object.

21. Berg $M$. The Age of Manufactures 1700-1820: Industry, Innovation and Work in Britain, 2nd ed. (London and New York: Routledge, 1994), URL: http://dx.doi.org/10.4324/9780203990 971.

22. Bourget M. N; Licoppe Ch. and Sibum H. O. (eds.). Instruments, Travel and Science: Itineraries of Precision from the Seventeenth to the Twentieth Century (London and New York: Routledge, 2002). -pp.145-160. DOI: http://dx.doi.org/10.4324/97802032190 10.

23. Elisabeth G. Gasparo Contarini: Venice, Rome, and Reform. Berkely: University of California Press.1993.URL: http://ark.cdlib.org/ark:/13030/ft42900 5 s2.

24. Harry A. "The Economy of Early Renaissance Europe, 1300-1460".

25. Plumb J. H; Bishop; Morris. The Italian Renaissance, Mariner Books, 2001. -pp. 78-80

URL: https://www.goodreads.com/book/sh ow/415600. 